\title{
YOUTUBE NA LEKCJI JEZZYKA POLSKIEGO JAKO OBCEGO
}

SŁowa KLUCZOWE: YouTube, NAUCZANIE JĘZYKa POLSKIEGO JAKO OBCEGO, MEDIA, KULTURA, ROZRYWKA

\section{WSTĘP}

„Młode pokolenie XX wieku, 'wychowane na telewizji' i korzystające w szerokim stopniu z masowych środków przekazu informacji, przyzwyczajone jest do przyjmowania wiedzy w oparciu o obraz i odpowiednio przystosowany do niego komentarz" - tak w roku 1980 pisał Jerzy Brzeziński o pokoleniu, które ówcześni glottodydaktycy nauczali. Obecne młode pokolenie z przełomu XX i XXI wieku to pokolenie Internetu, następcy pokolenia telewizji, a obecni lektorzy to w dużej mierze dorosłe pokolenie telewizji. Lektorzy ci chętnie sięgają po różnego rodzaju multimedia, które urozmaicają lekcje języka polskiego jako obcego, ponieważ sami, gdy byli młodzi, lubili urozmaicone lekcje. Można powiedzieć, że współcześni studenci wychowani w dobie Internetu, wręcz wymagają od nauczyciela korzystania podczas lekcji z filmików, piosenek czy animacji ${ }^{1}$.

Jako lektor języka polskiego jako obcego często korzystam z tego typu środków dydaktycznych, a przygotowując blok lekcyjny, staram się, żeby chociaż kilka minut było wypełnionych multimediami, które najlepiej, gdyby były umieszczone jako przerywnik w połowie czasu lekcyjnego, aby po prostu pobudzić, uaktywnić studentów. Najczęściej sięgam po materiały opublikowane w serwisie YouTube, ponieważ

${ }^{1}$ Współczesne lekcje nie powinny już być zwykłymi lekcjami języka polskiego jako obcego (jpjo), gdzie korzystamy wyłącznie z tablicy oraz podręcznika, ale powinny to być lekcje języka polskiego jako obcego 2.0 (jpjo 2.0), czyli takie gdzie wykorzystywane są różnorodne multimedia i pokazywana jest kultura popularna [patrz Kajak 2012]. 
można tam znaleźć wiele interesujących multimediów na niemalże każdy temat. Portal ten ciągle jest uzupełniany i rozwijany, dlatego jeśli czegoś nie można znaleźć dzisiaj, to jest duże prawdopodobieństwo, że za jakiś czas pojawi się na YouTubie. Potencjał tego portalu dostrzegło już kilka polskich szkół językowych, które uczą między innymi języka polskiego jako obcego. Szkoły te publikują na portalu filmiki, które pozwalają studentom utrwalać poznane podczas lektoratu elementy języka polskiego. Nieco więcej na ten temat przedstawię w dalszej części artykułu. Nasuwa się pytanie - czy wykorzystanie podczas zajęć filmików umieszczonych w serwisie YouTube jest legalne?

\section{YouTube A PRAWo}

Na pytanie - czy można legalnie używać materiałów pozyskanych z portalu YouTube - odpowiedź można znaleźć na wielu forach internetowych poświęconych prawu. Przykładowo identyczne pytanie na temat legalności użycia filmów z portalu YouTube nurtowało jednego z użytkowników forum legalnakultura.pl, który zadał tam następujące pytania:

Jestem nauczycielem i chciałbym wykorzystać na lekcji materiały z YouTube. Chciałbym to odtwarzać publicznie podczas lekcji, stąd pytanie czy to jest legalne? Czy, z powodu problemów z prezentacją online, mogę takie filmy ściągnąć i odtwarzać legalnie z komputera? Czy ingerencja w taki ściągnięty film, np. skrócenie go, jest legalne? Czasem nie wszystko jest ciekawe, a pilnowanie na lekcji, w której sekundzie filmik wyłączyć jest czasochłonne.

(www.legalnakultura.pl/pl/prawo-w-kulturze/zapytaj-prawnika/blog/343)

Odpowiedzi na powyższe pytania udzieliła prawniczka - Emilia Chmielewska:

Zasadniczo na wykorzystywanie rozpowszechnionych utworów bez uprzedniego uzyskania zgody w ramach szkół i innych placówek dydaktycznych lub naukowych zezwala art. 27 ustawy o prawie autorskim. Stanowi on, iż ,instytucje naukowe i oświatowe mogą, w celach dydaktycznych lub prowadzenia własnych badań, korzystać z rozpowszechnionych utworów w oryginale i w thumaczeniu oraz sporządzać w tym celu egzemplarze fragmentów rozpowszechnionego utworu".

Emilia Chmielewska (prawnik), Traple Konarski Podrecki i Wspólnicy sp.j.

(www.legalnakultura.pl/pl/prawo-w-kulturze/zapytaj-prawnika/blog/343)

Reasumując, lektorzy języka polskiego, zarówno podczas lekcji grupowych, jak i nauki indywidualnej mogą korzystać z filmów opublikowanych na YouTubie. Mogą wykorzystywać całe materiały, a także ich fragmenty.

Znając polskie realia, wiem, że zdarza się, iż w jednostce, w której prowadzimy lektorat z języka polskiego jako obcego nie ma dostępu, stałego lub tymczasowego, do Internetu, wówczas lekcja przygotowana na podstawie materiałów pochodzących z portalu YouTube nie może być właściwie zrealizowana. Chyba że lektor wcześniej pobrał z tego portalu potrzebne materiały, ale tu pojawia się pytanie - jak można je uzyskać? 


\section{Pobieranie materialów z YouTube}

Istnieje wiele stron internetowych umożliwiających pobieranie filmów z YouTube'a, ale z doświadczenia wiem, że część z nich jest płatna, a część pozwala pobrać wyłącznie filmiki w niskiej jakość, inne strony z kolei są bardzo skomplikowane w obsłudze. Sam natomiast po przetestowaniu wielu z tych portali korzystam z jednego bardzo prostego sposobu pobierania filmów z YouTube'a. Poniżej prezentuję krótką instrukcję korzystania ze strony, która umożliwia w prosty sposób pobieranie plików. Uwaga! Aby skorzystać z tego sposobu, trzeba mieć poprawnie skonfigurowany komputer, to znaczy zainstalowany program Java, który można bezpłatnie pobrać ze strony www.java.com/pl/download/. Następnie trzeba w panelu starowania komputera zmniejszyć poziom zabezpieczeń pobranego programu. Kiedy już to wszystko zrobimy, otwieramy stronę z filmem, który chcemy pobrać, np. reklamę z Jerzym Bralczykiem w roli głównej „Wyłączamy prąd. Włączamy oszczędzanie" (grafika 1) i modyfikujemy adres strony internetowej poprzez dodanie po wyrazie „youtube” słowa kluczowego „-get” (grafika 2). Na przykład www.youtube. $\mathrm{com} /$ watch? $\mathrm{v}=$ avi10vlsH0Y zamieniamy na www.youtube-get.com/watch? $\mathrm{v}=$ avi10vlsH0Y i naciskamy przycisk enter na klawiaturze, aby przejść do nowej strony.

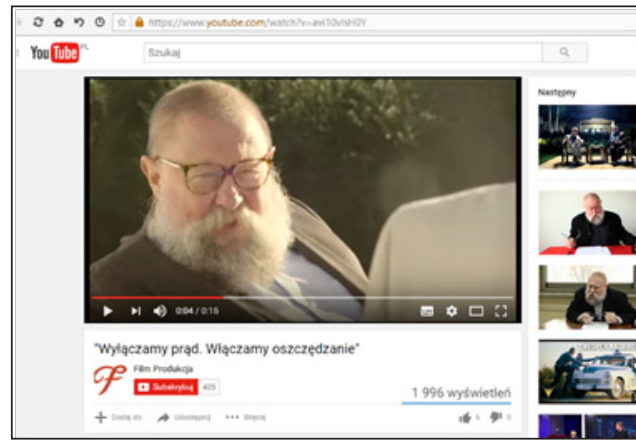

GRAFIKA 1

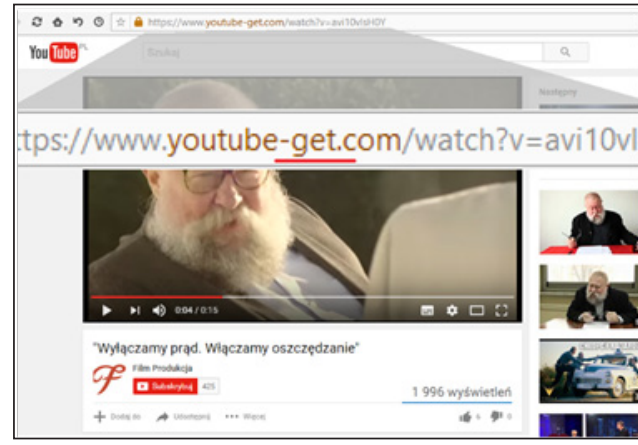

GRAFIKA 2

Akceptujemy jedno lub dwa okienka z zabezpieczeniami (grafika 3), różnica w ich liczbie jest uzależniania od typu przeglądarki. Gdy otworzy się właściwa strona internetowa (grafika 4), klikamy po prawej stronie na jeden z obrazków przypominających klatki taśmy filmowej i pobieramy film w wybranym przez nas formacie. Możliwe do pobrania formaty umieszczone są pod obrazkami klatek filmowych, np. MP4 czy 3GP. Po zakończeniu pobierania plik zostanie zapisany na dysku twardym naszego komputera.

Jeśli natomiast nie mamy dobrze skonfigurowanego komputera i nie wyświetla nam się prawidłowo strona umożliwiająca pobranie filmików (grafika 5), to twórcy portalu dają inną możliwość ściągnięcia interesującego nas pliku. Wystarczy kliknąć napis „download”, który znajduje się na górze strony (grafika 6) i pobrać niewielki program, dzięki któremu już zawsze będziemy mogli bezproblemowo pobierać pliki z portalu YouTube. Warto go zapisać np. na pulpicie, żeby zawsze był widoczny. 


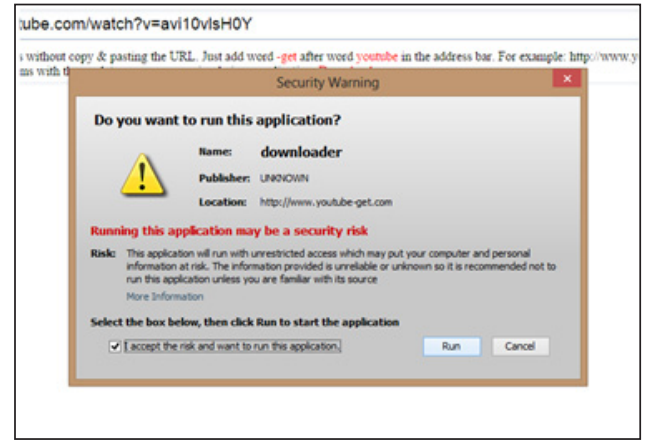

GRAFIKA 3

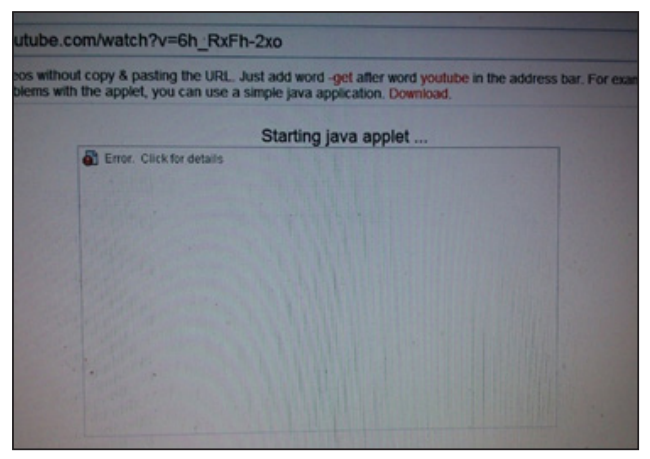

GRAFIKA 5

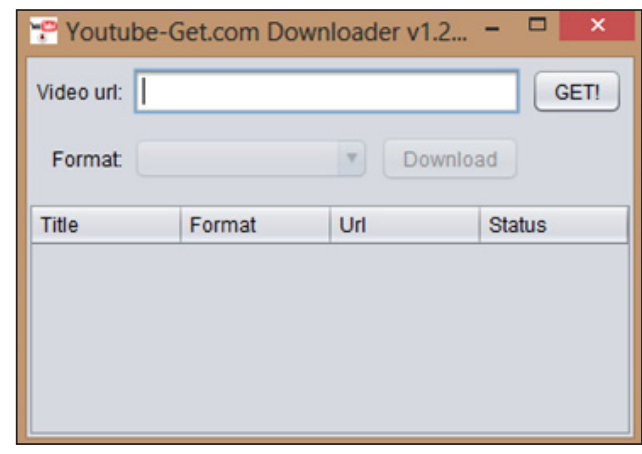

GRAFIKA 7

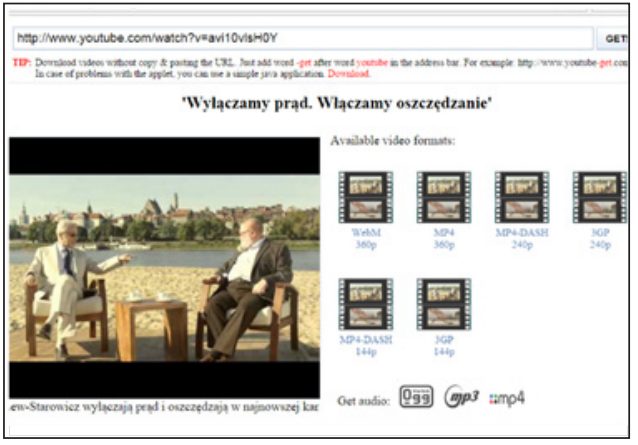

GRAFIKA 4

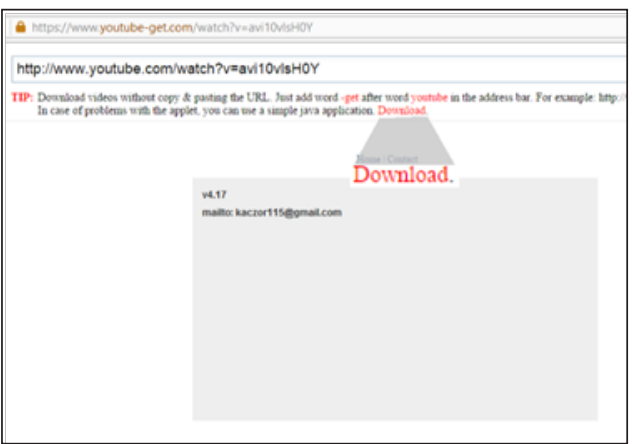

GRAFIKA 6

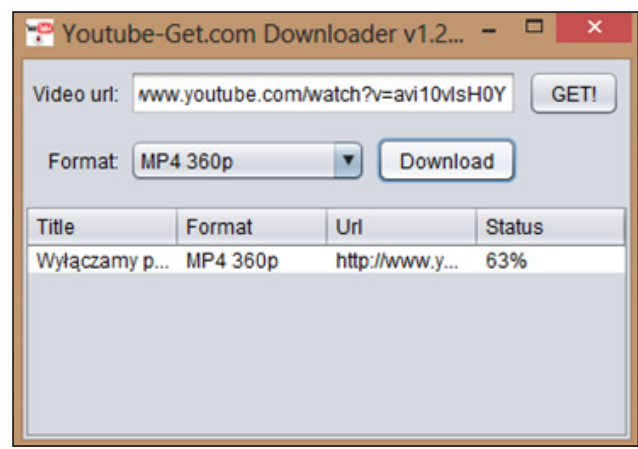

GRAFIKA 8

Po pobraniu i uruchomieniu programu powinno otworzyć się okienko, które zilustrowane zostało na grafice 7. Następnie w polu „Video url” wpisujemy adres interesującego nas filmu opublikowanego na YouTubie. Wybieramy format filmu i naciskamy przycisk „Download” (grafika 8).

Gdy już wiemy, jak pobierać interesujące nas materiały z portalu YouTube, zobaczmy, jak możemy je wykorzystać na lektoracie języka polskiego jako obcego. Prezentowane poniżej materiały zostały przeze mnie sprawdzone i wykorzystane na lekcjach języka polskiego. 


\section{Przykeady ĆWiczeń z WyKorzystaniem Materialów z PORTalu YouTube}

\subsection{ReCYTACJe (NA PRZYKEadzie LoKomotywy JUliana TuWima) - POZIOM A2/B1}

Ćwiczenie rozpoczynamy od rozdania słuchaczom tekstu wiersza Juliana Tuwima, w którym brakuje kilku rzeczowników, i prosimy, aby go przeczytali oraz podkreślili niezrozumiałe wyrazy, które następnie im tłumaczymy. Karta pracy do tego ćwiczenia wygląda następująco:

\begin{tabular}{|c|c|}
\hline 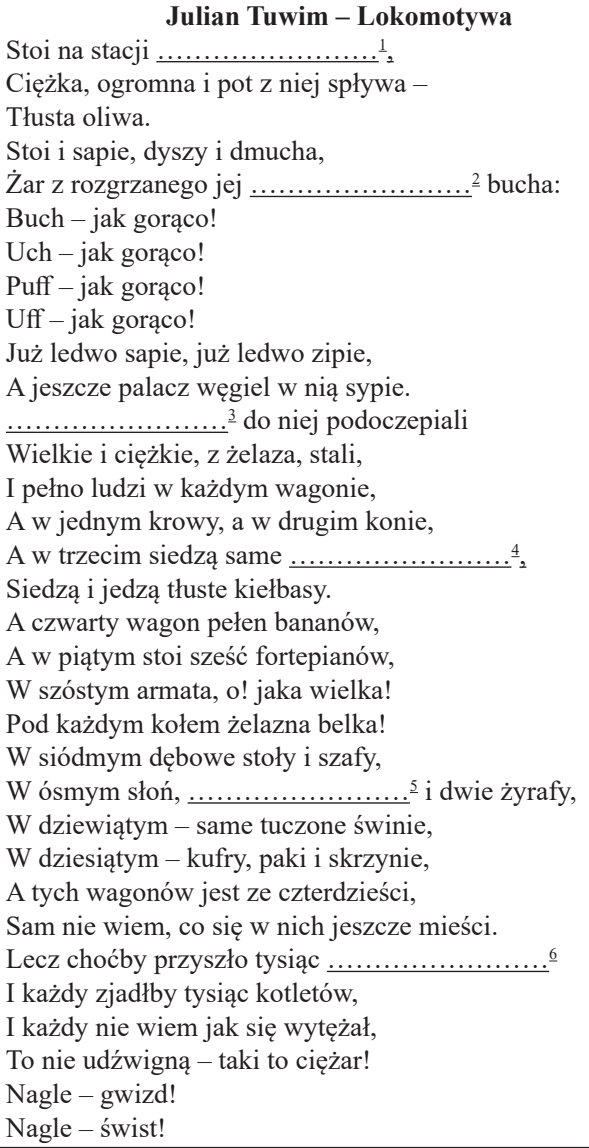 & $\begin{array}{l}\text { Para - buch! } \\
\text { Koła - w ruch! } \\
\text { Najpierw } \\
\text { powoli } \\
\text { jak żółw } \\
\text { ociężale } \\
\text { Ruszyła } \\
\text { maszyna } \\
\text { po szynach } \\
\text { ospale. } \\
\text { Szarpnęła wagony i ciągnie z mozołem, } \\
\text { I kręci się, kręci się koło za kołem, } \\
\text { I biegu przyspiesza, i gna coraz prędzej, } \\
\text { I dudni, i stuka, łomoce i pędzi. } \\
\text { A dokąd? A dokąd? A dokąd? Na wprost! } \\
\text { Po torze, po torze, po torze, przez most, } \\
\text { Przez góry, przez tunel, przez pola, przez las } \\
\text { I spieszy się, spieszy, by zdążyć na czas, } \\
\text { Do taktu turkoce i puka, i stuka to: } \\
\text { Tak to to, tak to to, tak to to, tak to to, } \\
\text { Gładko tak, lekko tak toczy się w dal, } \\
\text { Jak gdyby to była piłeczka, nie stal, } \\
\text { Nie ciężka maszyna zziajana, zdyszana, } \\
\text { Lecz fraszka, igraszka, zabawka blaszana. } \\
\text { A skądże to, jakże to, czemu tak gna? } \\
\text { A co to to, co to to, kto to tak pcha? } \\
\text { Że pędzi, że wali, że bucha, buch-buch? } \\
\text { To para gorąca wprawiła to w ruch, } \\
\text { To para, co z kotła rurami do tłoków, } \\
\text { A tłoki kołami ruszają z dwóch boków } \\
\text { I gnają, i pchają, i pociąg się toczy, } \\
\text { Bo para te tłoki wciąż tłoczy i tłoczy, } \\
\text { I koła turkocą, i puka, i stuka to: } \\
\text { Tak to to, tak to to, tak to to, tak to to!... }\end{array}$ \\
\hline
\end{tabular}

Klucz: 1 - lokomotywa, 2 - brzucha, 3 - wagony, 4 - grubasy, 5 - niedźwiedź, 6 - atletów Tekst pochodzi ze strony: www.czasdzieci.pl/czytanki/id,1274b6-lokomotywa.html

Uruchamiamy filmik, który jest mistrzowską recytacją wiersza w wykonaniu Wojciecha Pszoniaka, Daniela Olbrychskiego i Piotra Fronczewskiego (film nagrany został w 1979 roku, a zobaczyć go można na stronie: www.youtube.com/watch?v=NLT_Yx5yhGo). Studenci podczas trwania nagrania słuchają, oglądają i uzupełniają brakujące fragmenty w pierwszej części tekstu, które celowo występują tylko na początku, ponieważ podczas drugiej części filmu słuchacze muszą mieć 
czas, by przyjrzeć się występującym recytatorom. Po obejrzeniu filmu sprawdzamy luki w tekście i prosimy studentów, aby opisali wygląd aktorów. Następnie pokazujemy plansze ze współczesnymi wizerunkami recytatorów (grafika 9, 10 i 11) i także prosimy o opisanie ich lub, w bardziej zaawansowanej językowo grupie, możemy poprosić o porównanie aktorów z 1979 roku z ich obecnymi wizerunkami.

Na zakończenie ćwiczenia pokazujemy planszę ze zdjęciami Juliana Tuwima (grafika 12), a następnie opowiadamy o nim i opisujemy go.

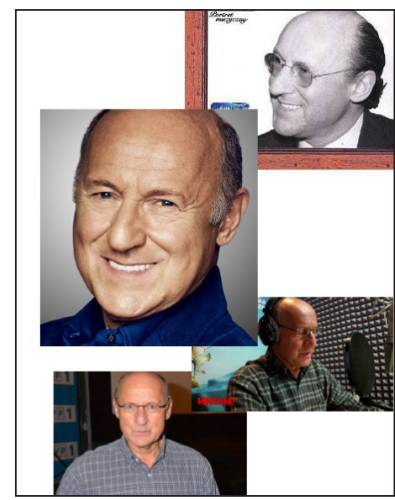

GRAFIKA $9^{2}$

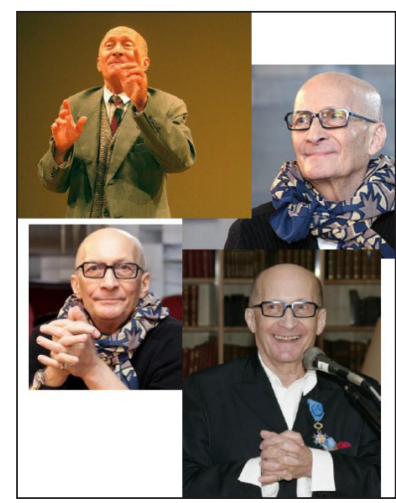

GRAFIKA $10^{3}$

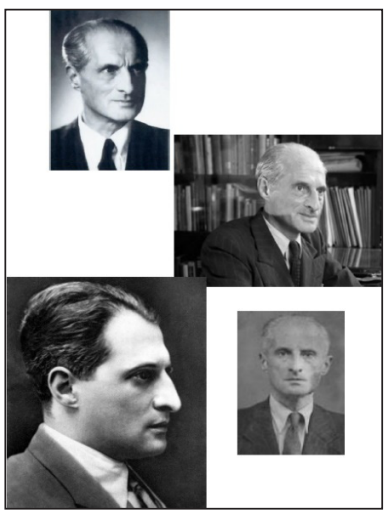

GRAFIKA $12^{5}$

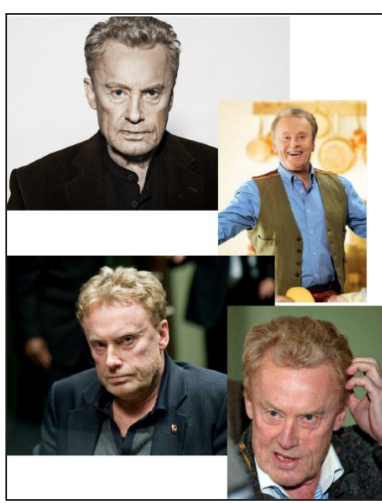

GRAFIKA $11^{4}$

${ }^{2}$ Do stworzenia planszy wykorzystano zdjęcia z następujących stron internetowych: www.teatr6pietro.pl/ artysci/piotr-fronczewski; www.empik.com/portrety-zlota-kolekcja-fronczewski-piotr,182523,muzyka-p; www.managerplus.pl/piotr-fronczewski-nowym-glosem-kampanii-pkp-sa-i-pkp-intercity/; www.fronda.pl/a/ piekne-wyznanie-wiary-piotra-fronczewskiego-masz-dosc-wynurzen-celebrytow-zobacz,75008.html.

${ }^{3}$ Do stworzenia planszy wykorzystano zdjęcia z następujących stron internetowych: www.pl.wikipedia.org/wiki/Wojciech_Pszoniak; www.film.onet.pl/wojciech-pszoniak; www.pachniewicz.wordpress.com/2010/10/04/; www.toya.net.pl/portal/kino/aktor/4874.

${ }^{4}$ Do stworzenia planszy wykorzystano zdjęcia z następujących stron internetowych: www.culture.pl/pl/ artykul/olbrychski-jako-ksiadz-w-filmie-cud; www.gala.pl/artykul/daniel-olbrychski-mialem-nadmiar-dobrych-kart; www.kozaczek.pl/plotka.php?id=42955; www.alchetron.com/Daniel-Olbrychski-299961.

${ }^{5}$ Do stworzenia planszy wykorzystano zdjęcia z następujących stron internetowych: www.zss1. tarnobrzeg.pl/goniec/?p=564; www.stairway.blox.pl/2013/02/Rok-Juliana-Tuwima.html; www.tuwim.org/index. php?galeria; www.slideshare.net/BeataMinta1/julian-tuwim-51774203. 


\subsection{Piosenki DLA DOROSEYCH \\ (NA PRZykŁadzie KLubu Wesolego Szampana \\ FormacJi NiEżywych SchabufF) \\ - POZIOM B1}

Warto szukać piosenek, w których powtarzana jest pewna struktura zdaniowa, jak na przykład utwór Klubu Wesołego Szampana, który zbudowany został w oparciu o tryb przypuszczający, dlatego też idealnie nadaje się do tego, by utrwalać konstrukcje tego trybu. Ćwiczenie zaczynamy od rozdania kart pracy:

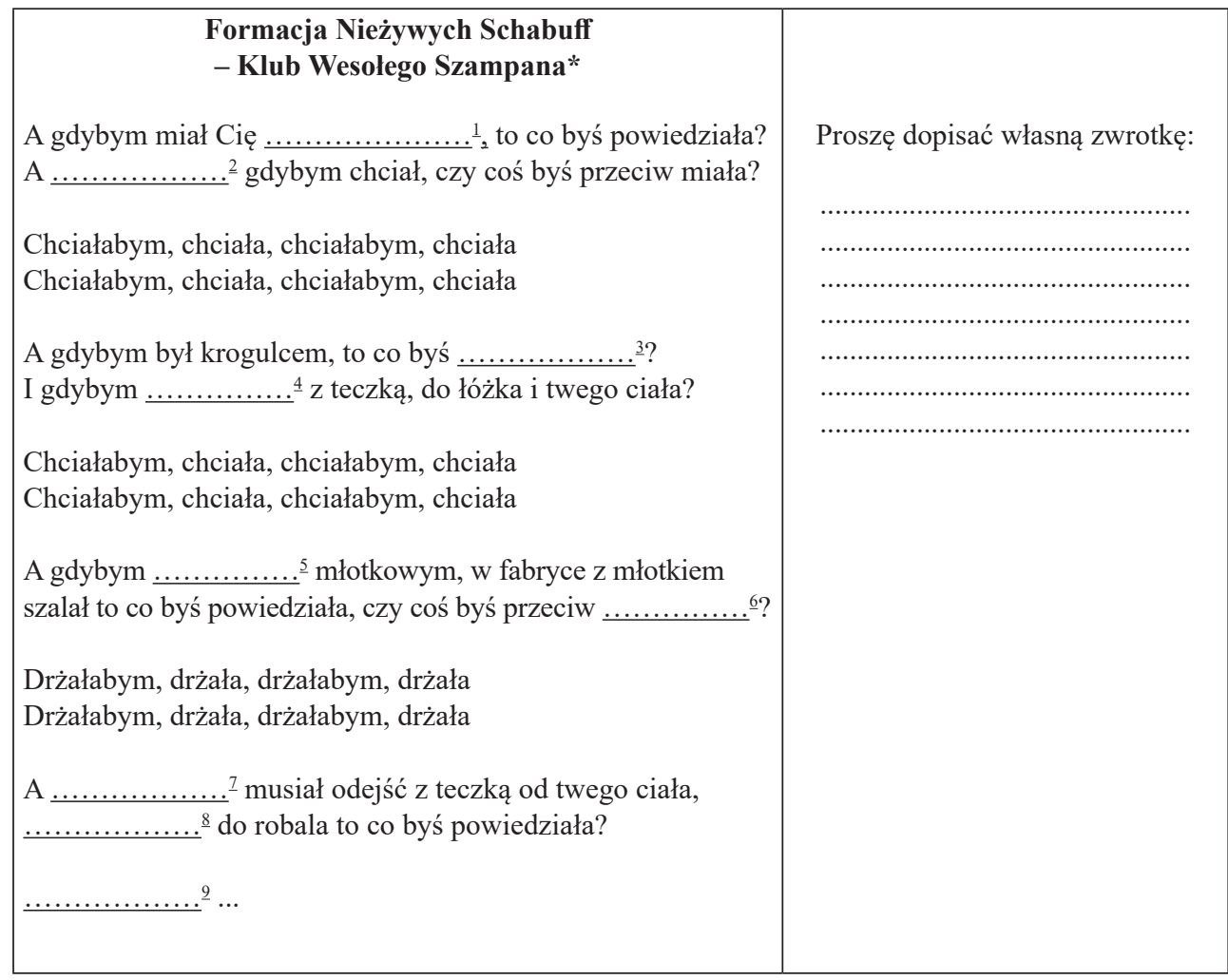

Klucz: 1 -zjeść, 2 - ugryźć, 3 - powiedziała, 4 -przyszedł, 5 - był, 6 - miała, 7 -gdybym, 8 - uciekać, 9 - żałowałabym

* Tekst pochodzi ze strony: www.tekstowo.pl/piosenka,formacja_niezywych_schabuff,klub_wesolego_szampana.html

Prosimy studentów, aby zapoznali się z tekstem, a następnie uruchamiamy filmik z amatorskim teledyskiem do piosenki (www.youtube.com $/$ watch? $=\mathrm{o}_{-} \mathrm{Y}$ -M4IiZK8). Teledysk zawiera tekst utworu, dlatego podczas pierwszego słuchania nie można pokazywać słuchaczom ekranu monitora. Sprawdzamy luki i odtwarzamy teledysk jeszcze raz, w tym momencie można już pokazać tekst towarzyszący piosence, utrwali to pisownię cząstki „by” z różnymi czasownikami w trybie 
przypuszczającym. Na zakończenie ćwiczenia prosimy studentów, aby sami stworzyli zwrotkę piosenki, a następnie ją odczytali.

\subsection{Piosenki DLA DZieCI \\ (NA PRZYKLADZIE DOMOWYCH SPRZĘTÓW ELEKTRYCZNYCH) - POZIOM A1}

Analogicznie jak w poprzednich ćwiczeniach, tak i tutaj pracujemy z tekstem, w którym umieszczono kilka luk. Karta pracy tego ćwiczenia wygląda następująco:

\begin{tabular}{|c|c|}
\hline 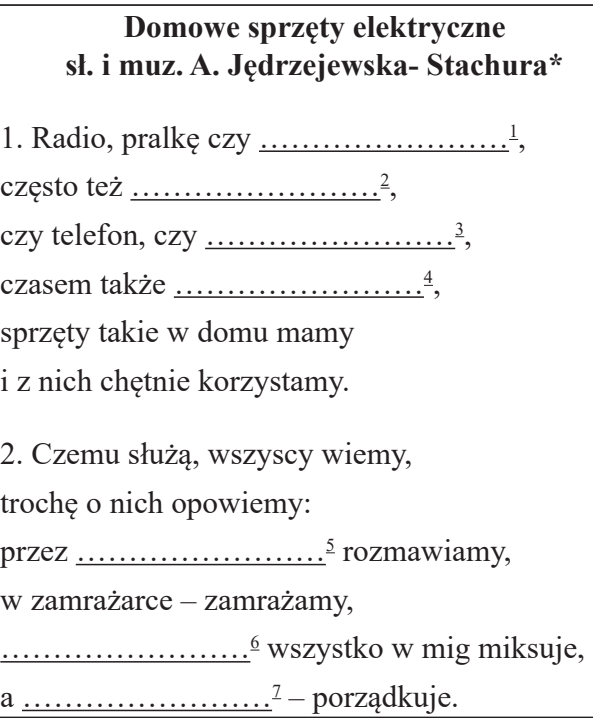 & 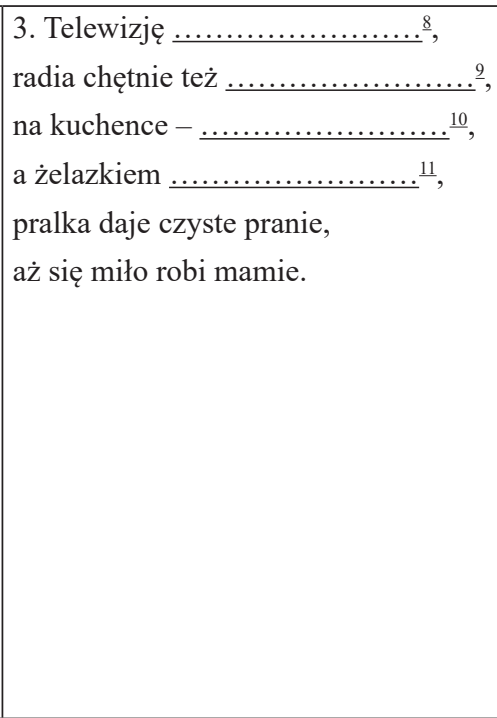 \\
\hline
\end{tabular}

Klucz: 1 - lodówkę, 2 - sokowirówkę, 3 - suszarkę, 4 -zamrażarkę, 5 - telefon, 6 - mikser, 7 - odkurzacz, 8 - oglądamy, 9 - słuchamy, 10 - gotujemy, 11 - prasujemy

* Tekst pochodzi ze strony: www.mp17siedlce.net/grupy/gr-4-wesole-nutki/81-piosenka-domowesprzety-elektryczne-sl-i-muz-a-jedrzejewska-stachura

Ważne, aby tekst z kolumny lewej znalazł się innej stronie niż tekst z prawej. Chodzi o to, by studenci nie widzieli ostatniej zwrotki piosenki. Amatorski teledysk do tego utworu wzbogacony został o pokaz slajdów, w którym prezentowane są przedmioty elektryczne codziennego użytku (teledysk dostępny na stronie: www. youtube.com/watch? $\left.\mathrm{v}=\mathrm{O} \_Y-p 4 o i Z K 8\right)$. Uruchamiamy piosenkę, kierując ekran w stronę studentów. Utwór należy odtworzyć dwukrotnie. Następnie sprawdzamy luki, w których trzeba było wstawić odpowiedni rzeczownik, i przechodzimy do zwrotki trzeciej. Prosimy studentów, by sami lub w parach intuicyjnie uzupełnili tekst odpowiednimi czasownikami. Sprawdzamy komu udało się wykonać zadanie, a tym, którzy mają problem z ćwiczeniem pomagamy. Na koniec rozdajemy obrazki (grafiki 13 i 14) i prosimy o uzupełnienie nazw przedmiotów. Wpisana pierwsza litera i kropki, które oznaczają liczbę liter w wyrazie, mają na celu ułatwienie wykonania tego zadania. 


\subsection{FILMY EDUKACYJNE I ROZRYWKOWE \\ (NA PRZYKLADZIE HISTORII INTEGRACJI EUROPEJSKIEJ \\ ORAZ MATURA TO BZDURA) \\ - POZIOM B1/B2}

Ćwiczenie dla grupy zaawansowanej językowo. Najlepiej zrealizować je w grupie polonijnej, która w przyszłości chce studiować ekonomię lub stosunki międzynarodowe. Początek ćwiczenia polega na rozdaniu kart pracy:

\section{Unia Europejska}

1) Ile gwiazdek jest na fladze Unii Europejskiej?

2) Jak nazywa się hymn Unii Europejskiej?

3) W którym roku Polska wstąpiła do Unii Europejskiej?

4) Czy Ukraina należy do Unii Europejskiej?

5) Czy Norwegia należy do Unii Europejskiej?

6) Gdzie znajduję się siedziba Parlamentu Europejskiego?

7) Które miasto jest umowną stolicą Unii Europejskiej?

8) Kto w latach 2009-2012 był przewodniczącym Parlamentu Europejskiego?

9) Rozszyfruj skróty:

EWG

EWWiS

10) Czy Rumunia należy do Unii Europejskiej?

11) Co to jest strefa Schengen?

Klucz: 1 - 12, 2 - Oda do Radości, 3 - 2004, 4 - nie, 5 - nie, 6 - w Strasburgu, 7 - Bruksela, 8 - Jerzy Buzek, 9 - EWG (Europejska Wspólnota Gospodarcza), EWWiS (Europejska Wspólnota Węgla i Stali), 10 - tak, 11 - strefa, w której zniesiono kontrolę osób przekraczających granice między państwami członkowskimi układu z Schengen

Prosimy studentów, aby odpowiedzieli na pytania, po czym uruchamiamy film edukacyjny Historia integracji europejskiej (dostępny na stronie: www.youtube. $\mathrm{com} /$ watch? $\mathrm{v}=\mathrm{qgQLYflExMc}$ ). Ze względu na długość tego filmu najlepiej pokazać tylko te jego fragmenty, w których występują odpowiedzi na powyższe, umieszczone w karcie pracy pytania. Następnie sprawdzamy odpowiedzi i na koniec, aby rozbawić słuchaczy, uruchamiamy poświęcony tematyce Unii Europejskiej odcinek programu rozrywkowego Matura to Bzdura (film dostępny na stronie: www.youtube.com/watch?v=MMBt7_wumYA), w którym przypadkowo zapytani Polacy odpowiadali na identyczne pytania, które wystąpiły przed chwilą w karcie pracy. Ludzie pytani podczas sondy ulicznej, często mylili się w odpowiedziach lub przynajmniej częściowo mijali się z prawdą. 


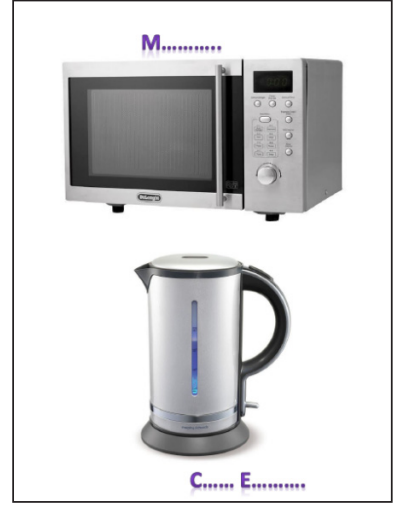

GRAFIKA $13^{6}$

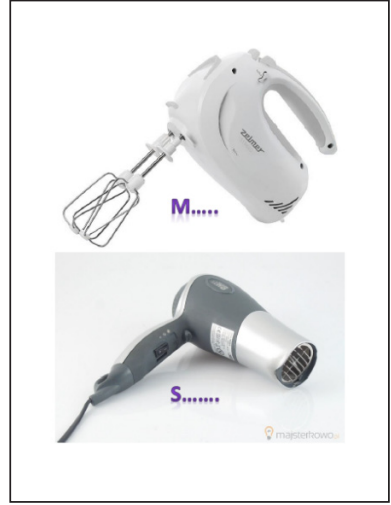

GRAFIKA $14^{7}$

\subsection{FILMY KONTROWERSYJNE (NA PRZYKŁADZIE WYPOWIEDZI WOJCIECHA CEJROWSKIEgo) - POZIOM B2}

W grupie zaawansowanej językowo można sięgnąć po kontrowersyjne wypowiedzi, które są punktem wyjścia do rozmowy na dany temat. Podczas lektoratu można np. odtworzyć film z wypowiedzią Wojciecha Cejrowskiego (film można zobaczyć na stronie: www.youtube.com/watch? $\mathrm{v}=\mathrm{Pj} I \mathrm{leklb} 4 \mathrm{hHw}$ ), który mówi:

Proszę się nie uczyć języków, to nie ma sensu. W każdym kraju jest inny język. Jak się człowiek nauczy angielskiego i pojedzie do Chin no to, to jest absurdalna sytuacja, kiedy dla obu stron ten język jest językiem obcym. To już lepiej, jak oni mówią do nas po chińsku, bo dla nich to jest język narodowy. My do nich mówimy po polsku, dla nas to jest język oswojony, wtedy przekaz medialny, mimika naszej twarzy, nasze gesty zgadzają się z przekazywaną treścią, a jak Państwo próbują w obcym kraju mówić po niemiecku albo po angielsku i dla obu stron to są obce języki. Dla nas drugi dla nich też drugi, to twarz mówi co innego niż usta (...).

Wojciech Cejrowski, Międzynarodowe Targi Turystyczne, 5-7 kwietnia 2013

Cejrowski tę dość kontrowersyjną tezę, że nie warto uczyć się języków, przedstawia, wzbogacając wieloma zabawnymi przykładami, często przy tym ironizując. Film ten idealnie nadaje się jako wstęp do lekcji, której tematyką są np. języki obce. Pytamy wtedy studentów: czy zgadzają się z opinią Cejrowskiego, czy znają jakieś inne języki obce niż polski, ile znają języków, co sprawia im największą trudność przy poznawaniu języka polskiego, a co jest w nim najłatwiejsze itd.

${ }^{6}$ Do stworzenia planszy wykorzystano zdjęcia z następujących stron internetowych: www.allegro.pl/ artykul/kuchenka-mikrofalowa-z-funkcja-gotowania-na-parze-czy-parowar-co-lepiej-wybrac-56229; www.rtvagd.wp.pl/kat,news,query,czajnik\%20elektryczny,szukaj.html?ticaid=1183a7.

${ }^{7}$ Do stworzenia planszy wykorzystano zdjęcia z następujących stron internetowych: www.euro. com.pl/miksery-reczne.bhtml; www.fit.pl/mobi/152/suszarka-do-wlosow-ma-100-lat,14.html. 


\section{INNE FILMIKI Z PORTALU YOUTUBE}

\subsection{Filmy I ANIMACJE NIEME - POZIOM OD A1 Do C2}

Zajęcia można wzbogacić np. animacją Tomka Bagińskiego pt. Katedra. I w zależności od poziomu grupy tworzyć pytania i ćwiczenia do tego typu filmów. Na poziomie A można poprosić o opisanie wyglądu postaci lub tytułowej katedry, zaś na poziomie $\mathrm{B}$ lub $\mathrm{C}$ o interpretację filmu.

\subsection{FilMY REKLAMOWE - POZIOM OD A1 DO C2 ${ }^{8}$}

Na YouTubie znaleźć można wiele reklam, od bardzo prostych, które pokazują wyłącznie dany produkt, jego specyfikację i cenę, po te bardziej wyszukane wykorzystujące popularnych aktorów i posiadające rozbudowany scenariusz. $\mathrm{Na}$ przykład grupie z poziomu A można pokazać prostą reklamę z wyciszoną nazwą produktu i poprosić o nazwanie go, a na bardziej zaawansowanych poziomach poprosić o stworzenie własnej reklamy, na wzór tej pokazanej podczas lektoratu.

\subsection{FILMY SZKóŁ JĘZYKOWYCH (KURSY JĘZYKOWE) - POZIOM A1 DO C2}

Coraz więcej szkół decyduje się na umieszczanie filmów edukacyjnych na portalu YouTube, np. POLONUS Łódzka Szkoła Języka Polskiego dla Cudzoziemców, od 2 lat nieprzerwanie publikuje nowe filmy, które mają na celu uczyć pewnych aspektów języka polskiego (filmy dostępne są na stronie: www.youtube.com/channel/ UC9SeBSyrxEMtEU1QNjG3vTA/videos).

\section{Podsumowanie}

Podsumowując, YouTube jest niesamowitym narzędziem pomagającym lektorowi języka polskiego jako obcego w urozmaiceniu zajęć. Niezależnie od tematyki konkretnych lekcji czy też rozwijanej w danym momencie sprawności językowej, zawsze znajdzie się coś na portalu YouTube, co będzie pasowało do planowanych zajęć. Współczesny wzorowy lektor musi wręcz korzystać podczas zajęć z różnych multimediów, bo lektor XXI wieku to pedagog, który „używa technologii komputerowej, by wprowadzić nauczany materiał, wzmocnić (uatrakcyjnić) kształcenie lub ocenić stopień jego przyswojenia" [Zarzycka 2014], a w tym zadaniu bardzo pomaga mu materiał pozyskany z portalu YouTube.

${ }^{8}$ Magdalena Foland-Kugler w jednym z artykułów podkreśla, że lektor powinien „Zwracać uwagę słuchaczy na nowinki reklamowe i na językowe triki, które często wchodzą do zbioru cytatów używanych na co dzień przez Polaków" [2005]. Podzielam to zdanie i myślę, że tematyka reklam powinna stanowić ważny element chociażby jednej lekcji języka polskiego jako obcego. 


\section{BibLiOgRAFIA}

Brzeziński J. [1980], Pomoce i środki audiowizualne w nauczaniu języków obcych, Państwowe Wydawnictwo Naukowe, Warszawa.

Foland-Kugler M. [2005], Cudzoziemiec wobec polskiej reklamy, [w:] Nauczanie języka polskiego jako obcego i polskiej kultury w nowej rzeczywistości europejskiej, Garncarek P. (red.), Zakład Graficzny Uniwersytetu Warszawskiego, Warszawa.

Kajak P. [2012], JPJO 2.0, [w:] Kultura popularna w nauczaniu języka polskiego jako obcego, Garncarek P., Kajak P. (red.), Zakład Graficzny Uniwersytetu Warszawskiego, Warszawa.

Zarzycka G. [2014], Media w nauczaniu języków obcych. Koncepcje teoretyczne $i$ wybrane rozwiazania metodyczne, „Acta Universitatis Lodziensis. Kształcenie Polonistyczne Cudzoziemców", nr 21, Glottodydaktyka-Media-Komunikacja. Negocjowanie znaczeń, Dembowska-Wosik I., Grochala B., Pałuszyńska E., Wojenka-Karasek M. (red.), Wydawnictwo Uniwersytetu Łódzkiego, Łódź.

www.legalnakultura.pl/p1/prawo-w-kulturze/zapytaj-prawnika/blog/343 